University of Nebraska - Lincoln

DigitalCommons@University of Nebraska - Lincoln

Agronomy \& Horticulture -- Faculty Publications

Agronomy and Horticulture Department

January 2005

\title{
Curiosities, nonsense, non-science and SRI
}

\author{
J. E. Sheehy \\ International Rice Research Institute, DAPO Box 7777, Metro Manila, Philippines \\ T. R. Sinclair \\ ARS-USDA \\ Kenneth G. Cassman \\ University of Nebraska-Lincoln, kcassman1@unl.edu
}

Follow this and additional works at: https://digitalcommons.unl.edu/agronomyfacpub

Part of the Plant Sciences Commons

Sheehy, J. E.; Sinclair, T. R.; and Cassman, Kenneth G., "Curiosities, nonsense, non-science and SRI" (2005). Agronomy \& Horticulture -- Faculty Publications. 72.

https://digitalcommons.unl.edu/agronomyfacpub/72

This Article is brought to you for free and open access by the Agronomy and Horticulture Department at DigitalCommons@University of Nebraska - Lincoln. It has been accepted for inclusion in Agronomy \& Horticulture -Faculty Publications by an authorized administrator of DigitalCommons@University of Nebraska - Lincoln. 


\title{
Discussion
}

\section{Curiosities, nonsense, non-science and SRI}

\author{
J.E. Sheehy ${ }^{\mathrm{a}, *}$, T.R. Sinclair ${ }^{\mathrm{b}}$, K.G. Cassman ${ }^{\mathrm{c}}$ \\ anternational Rice Research Institute, DAPO Box 7777, Metro Manila, Philippines \\ bARS-USDA, Agronomy Physiology Laboratory, P.O. Box 110965, Gainesville, FL 32611-0965, USA \\ '279 Plant Science Hall, Department of Agronomy and Horticulture, University of Nebraska-Lincoln, \\ P.O. Box 830915, Lincoln, NE 68583-0915, USA
}

Received 9 August 2004; received in revised form 14 August 2004; accepted 16 August 2004

The advocates of the system of rice intensification (SRI) have claimed both the world record for rice yield and the highest yields (by a substantial margin!) for any grain crop (Rafaralahy, 2002). This is curious because none of the usual information expected in support of these 'fantastic yields' was presented to support the claim. Absent were data concerning cultivar, experimental design, statistical errors, dates of planting and harvesting, soil types, fertilizer inputs, weed control, disease control, insect control, water management and the weather. Was the information withheld because they wanted to repeat the experiments and publish their incredible results in Nature or Science, before others beat them to it? Did they pause and wonder if they had discovered 'super' rice with a yield potential beyond that of any known grain crop? Oddly, the answer to both of those questions is no. Perhaps it escaped their notice that the energy required to achieve such a yield is well beyond the thermodynamic capabilities of plant photosynthesis and crop

\footnotetext{
* Corresponding author. Tel.: +63 2762 0127; fax: +6327612406.

E-mail address: j.sheehy@cgiar.org (J.E. Sheehy).
}

use of solar energy. Their carelessness with 'discovery', the pinnacle of scientific achievement, was matched only by their indifference to the commonly accepted protocols and principles of agronomic science (Sinclair and Cassman, 2004).

Like most advocates of nonsense, Stoop and Kassam (2004) suggest that it is the role of scientists to seek verification and confirmation of the SRI. They seem unaware that every genuine test of a theory, or a hypothesis, is an attempt to falsify it (Popper, 1989). Their sole test of the validity of any investigative work concerning SRI is whether it confirms their ideas. Indeed, in their letter they focus on claims that the work critical of SRI (Dobermann, 2003; Sheehy et al., 2004; Moser and Barrett, 2003) is flawed for not including a long list of mysterious components or, worse, they suggest that the authors and the 'anonymous' referees are part of a conspiracy of ignorance or vested interests. Such claims are not unusual outside the community of genuine scientists. The criticisms of Stoop and Kassam are not new, and the same comments occur repeatedly when members of the general public are disappointed that scientists do not eagerly pursue unsubstantiated, miraculous observations (Park, 2000). 
No doubt the admirers of SRI will continue in their advocacy and some funding agencies will waste money by diverting it from hypotheses developed with logical consideration of the relevant theory and substantive preliminary experiments. Eventually, SRI will go the way of other non-science and disappear into obscurity. The lesson of this exchange is how tenuous, and special, is the role of scientists in helping societies to invest wisely in the pursuit of knowledge and technological advances. This role is vital to support sustainable development-especially for the low-income rural population of developing countries that would benefit most from breakthroughs in agronomic technologies that increase productivity and reduce costs.

\section{References}

Dobermann, A., 2003. A critical assessment of the system of rice intensification (SRI). Agric. Syst. 79, 261-281.
Moser, C.M., Barrett, C.B., 2003. The disappointing adoption dynamics of a yield-increasing, low external-input technology: the case of SRI in Madagascar. Agric. Syst. 76, 1085-1100.

Park, R., 2000. Vodoo Science: The Road from Foolishness to Fraud. Oxford University Press, Oxford, UK.

Popper, K., 1989. Conjectures and Refutations: The Growth of Scientific Knowledge. Routledge, London.

Rafaralahy, S., 2002. An NGO perspective on SRI, its origins in Madagascar. In: Uphoff, N., Fernandes, E.C.M., Yuan, L.P., Peng, J.M., Rafaralahy, S., Rabenandrasana, J. (Eds.), Proceedings of an International Conference on Assessment of the System of Rice Intensification (SRI). Sanya, China, April 1-4, Cornell International Institute for Food, Agriculture and Development (CIIFAD), Ithaca, NY, http://ciifad.cornell.edu/sri/ proccontents.html (verified April 21, 2003), pp. 17-22.

Sheehy, J.E., Peng, S., Dobermann, A., Mitchell, P.L., Ferrer, A., Yang, J., Zou, Y., Zhong, X., Huang, J., 2004. Fantastic yields in the system of rice intensification: fact or fallacy? Field Crops Res. 88, 1-8.

Sinclair, T.R., Cassman, K.G., 2004. Agronomic UFOs? Field Crops Res. 88, 9-10.

Stoop, W.A., Kassam, A.H., 2004. The SRI controversy: a response. Field Crops Res., this issue. 